\title{
"The cinema needs the individual, and migrants need the cinema to re-emerge as an individual." Interview with Andrea Segre
}

"Le cinéma a besoin de l'individu, les migrants ont besoin du cinéma pour redevenir des individus ». Entretien avec Andrea Segre

«El cine necesita al individuo, los migrantes necesitan al cine para reconvertirse en individuos». Entrevista con Andrea Segre

\section{Constance De Gourcy}

\section{OpenEdition \\ Journals}

Electronic version

URL: https://journals.openedition.org/remi/8595

DOI: 10.4000/remi.8595

ISSN: $1777-5418$

This article is a translation of:

"Le cinéma a besoin de l'individu, les migrants ont besoin du cinéma pour redevenir des individus ». Entretien avec Andrea Segre - URL : https://journals.openedition.org/remi/8209 [fr]

Other translation(s):

Roma and Gypsies in the Mediterranean: Circulating Categories, Maintaining Boundaries - URL : https://journals.openedition.org/remi/8478 [en]

The Arab Spring: A Revolution for Egyptian Emigration? - URL : https://journals.openedition.org/remi/ 8481 [en]

Mapping the Migratory Movements - URL : https://journals.openedition.org/remi/8803 [en]

The measure of migratory flows between France and other countries; what if we also spoke of emigration? - URL : https://journals.openedition.org/remi/12090 [en]

Immigrant Youth in Canadian Postsecondary Education: Pathway Morphologies in the Province of

Quebec - URL : https://journals.openedition.org/remi/12100 [en]

Publisher

Université de Poitiers

Printed version

Date of publication: 1 December 2016

ISBN: 979-10-90426-29-0

ISSN: 0765-0752

\section{Electronic reference}

Constance De Gourcy, "'The cinema needs the individual, and migrants need the cinema to re-emerge as an individual." Interview with Andrea Segre", Revue européenne des migrations internationales [Online], vol. 32 - $n^{\circ} 3$ et 4 | 2016, Online since 01 December 2018, connection on 14 April 2022. URL: http:// journals.openedition.org/remi/8595 ; DOI: https://doi.org/10.4000/remi.8595 
This text was automatically generated on 14 April 2022.

(C) Université de Poitiers 


\title{
"The cinema needs the individual, and migrants need the cinema to re- emerge as an individual." Interview with Andrea Segre
}

\author{
"Le cinéma a besoin de l'individu, les migrants ont besoin du cinéma pour \\ redevenir des individus ». Entretien avec Andrea Segre \\ «El cine necesita al individuo, los migrantes necesitan al cine para reconvertirse \\ en individuos». Entrevista con Andrea Segre
}

Constance De Gourcy

1 How does the cinema see migration and circulation, and how does it open up the debate on these issues, in an increasingly globalized world? Many theorists, including some of the most well-known, have demonstrated cinema's ability to create distance (Barthes, 1975) or to introduce a different stance (Rancière, 2011) in order to highlight those aspects we do not usually see, while offering new and unprecedented configurations of what can be seen, said or thought ${ }^{1}$.

In recent decades, the migration question has become a major social issue for which cinema acts as a sounding board. Marc Ferro (2008: 259) has established a parallel between the growing number of films dealing with this theme in North American and European countries - including France, Great Britain and Germany - and the way these countries perceive themselves as they became multicultural and multi-ethnic societies from the 1960s onwards. Using films to debate migration issues involves a dual analysis: cinema as "the faithful witness of its time" (Gastaut, 2001) shows how a society constructs its relationship with Otherness through the portrayal of foreigners. It also contributes to an awareness of the history of migration in all its complexity with regard to its relationship with memory and forgetfulness.

3 By combining image and sound cinematographically and, in the same process, acting as an "identifier of problems and solutions that are relevant to the general public" 
(Chalvon-Demersay, 1996: 2), cinema benefits from a broad audience and thus contributes to the debate on the issues in question. ${ }^{2}$ Cinema's greatest strength lies in its social role: "it offers each of us an opportunity and the pleasure of speaking out, without being too intimidated, about artworks that we enjoy or that we detest" (Ethis, 2005: 5).

4 Andrea Segre's work draws on this twofold approach. As an Italian with a PhD in Sociology, a teacher, director and scriptwriter of internationally recognized and awardwinning films, he assumes his dual role career as sociologist and film-maker ${ }^{3}$ since it allows him to develop an unusual narrative form ${ }^{4}$ and thus explores in greater detail the complex and changing relationships between the world of migration and countries of destination. The approach he takes in his films, as a member of Italy's cinema engagé, ${ }^{5}$ covers a vast territory spreading from Europe to Africa, while focusing on areas with minority populations, frontier spaces between areas in transformation and in recomposition (multicultural suburbs, ports, abandoned sites, etc.), and places where newly-visible otherness generates a problematic co-existence (Berthomière and Hily, 2006). Mobility and migration, which traverse his cinema and which are filmed as they happen, are in fact major factors in the profound changes affecting increasingly urbanized territories and now-transnational economies. Unlike more "retro" filmic approaches, focusing more on an often suppressed migrant past (Bessy and Salmon, 2016), the most important events, at once unexpected and tragic, are the wellspring from which other rapports with reality can be structured in order to understand new representations of society. In this light, cinema can offer a "thinking x-ray" of its time (Eugène, 2015), alongside human and social sciences, with which "to talk about society" (Becker, 2010).

5 At a time when migration is seen as a problem, when images continually foster a public debate based on suspicion of strangers and fear of Otherness, it is important that we rediscover a sense of presence, no matter how transient, and this challenge runs through all his works. From his first documentary film, Lo sterminio dei popoli zingari released in 1998 when he was twenty-two, migration, constant new departures and forced halts leading to interrupted journeys have offered major opportunities for observing meaningful relationships in conflict over what is the Other and what is our common humanity. By making visible, or conversely placing what is visible in the background, by allowing the imagination to complete the scene, he has become a sociologist of his time, capable of extracting the most expressive interpretations, together with the tiny details that slip into the most ordinary of existences.

6 In this interview, Andrea Segre's approach to current migration issues is expressed through an innovative filmic language, revitalized by his theme, which is itself being permanently redefined. Following in the footsteps of the German sociologist Max Weber (2004 [1905]) who sought to define social change from the perspective of society's periphery, he describes and structures new worlds developing at the periphery, those "world's ends" (Agier, 2002), that multiply at the intersection of increasingly fragmented societies. Never reducing differences to particularities, he depicts the universal, non-ethnic dimension of Otherness in order to emphasize the strengths of humanity that they contain.

7 If this interview was inspired initially by a desire to clarify the complex relationships notably on the question of surveys ${ }^{6}$ - between sociology and cinema in the field of international migration, it also revealed another, broader, project, that is an invitation, 
an incentive to reflect on the driving force of representations as they influence our perceptions of the Other and the treatment of Otherness: by using words to deconstruct the power of images and using images to "restructure" the sense given to words, in order to extract the possibilities, over and above questions of security, which contribute to the management of migration: such is the objective for this dialogue which encourages us to practise civil resistance on a daily basis.

Constance De Gourcy (CDG): In a recent interview, 7 you mentioned that your Professor of Sociology once said to you: "If, sometime in the future, you find a way to talk about the world the way that Balzac did, then you can stop being a sociologist. If not, keep going". Can you tell us more about how you became a film producer and director, while continuing to work as a sociologist? How does this tie in with world emergencies on the "migration planet" (Simon, 2008)?

Andrea Segre (AS): I began making films in order to talk about the history of migration and the transformations that Italy was experiencing towards the end of the 1990s. Italy was undergoing major changes because of the arrival of migrants, a precursor for the situation that Europe had to face a few years later. At the time, I was twenty years old and I knew that something urgent and important was happening in my country and in neighbouring countries. I began to take an interest, I wanted to understand and talk about this and instinctively I thought that a camera was the best way to do this because it allowed me to record events happening a long way away and "bring them back" home. So I learnt how to use a camera and took it with me on my first trips to the Balkans, Bosnia and Albania in the late 1990s. While there, I began to make my first documentaries which closely reflected the international cooperation approach, notably the "decentralized cooperation" project used not by $\mathrm{NGOs}^{8}$ which work on large-scale humanitarian aid programmes, but rather by "small" non-centralized projects in their field of operations: so it was not so much an idea of large central organizations that help small suburbs, but of the suburbs themselves coming together and helping each other. Thanks to these projects, I had an opportunity, as a young Italian filmmaker, to go and work in Albania in collaboration with other young Albanian filmmakers. This collaboration, this cooperation, this reciprocity gave me my basic training, both as a human being and as a filmmaker. All my early documentaries evolved from conversations with people whose stories I recount in order that we can later "recount together" something that was bigger than ourselves. Increasingly, the human need to talk about what is within oneself became a professional necessity. As a result, I realized that I also had to learn how to use "cinema techniques" effectively: I had to study, see lots of films, lots of documentaries; in the 2000s, Italy was producing a large number of very interesting documentaries. They have proved to be a very useful tool, in my opinion, for liberating people from the dictatorship of the spectacle: a way of recounting the reality of situations in greater depth. Meanwhile, the phenomenon of immigration, of changes in Italian society has gradually become a global phenomenon, it is not just Italy that is changing, but our whole world; these changes are linked to the fact that people in difficulty and the less wealthy can no longer wait: they are on the move. They travel many miles and face great dangers, they travel because digital communications have facilitated the exchange of information and money (even during the journey!); they travel because they cannot wait any longer, they know that international aid is a farce and that, if they want to change their life, they must move their bodies themselves. Thus, what was previously a transformation merely for Italy has now become a transformation for Europe and for the whole world. The European 
Community has now begun to understand that migration is a question of global equilibrium: at one time, this phenomenon was described in terms of "yes, Italy is changing" or "yes, it's true, there are immigrants in Italy, ${ }^{9}$ but in France, Germany and England, there are many more". Now, Italy and Greece are the portals for a world that no longer wants to remain immobile. So, my films changed, they reacted to demands for narratives about human dynamics that do not focus solely on Italy, but on the whole of Europe.

To what extent can this desire to describe and demonstrate these changes through new images take advantage of cinematographic traditions? In other words, how have existing films helped you to fulfil your desire to create a new approach?

11 AS: Yes, some films have been important for me and have helped me to think this through. In particular, the Italian political films of the second generation of Neorealism: Elio Petri (1929-1982), Pasolini (1922-1975) to a certain extent, all films by Montaldo (1930), Gian Maria Volontè (1933-1994), and the world of Francesco Rosi (1922-2015), this is the world of political cinema, which is quite different from realism. Then, there were documentary films, the new Italian documentary films made in the last ten to fifteen years, I matured thanks to these films; and films by my friends and colleagues ${ }^{10}$ who are also making some very interesting documentaries, were equally important. They made me think, understand how we should encourage people to think, not by making a formal appeal saying "you must think!" but rather: "I am thinking about this, so let's think about it together". They were all making films that placed great importance on researching aesthetic forms, because what we were doing here was very ethical, but if we did not use a poetic and aesthetic medium, the films would fall flat, would not work, they would be boring for the public. All these films, I mean the films by Pasolini, Petri, and Rosi, have a very high aesthetic quality based on precise, aesthetic, experimental and specific research, as do most of the documentary films made by Italian directors in recent years. These people were all born with a documentary approach, they lived and evolved with it, but when it comes to the aesthetic image, they were interested in a very precise form of poetic sublimation.

CDG: Your relationship with cinema began with a meeting and a need to think differently about mass phenomena and the specific facts they reveal. How did cinema become the most suitable language for evoking not just the ethical, but also the political and social dimensions, and for portraying them as major issues in today's world? How does fiction make it possible to invent new ways of thinking and producing reality?

13 AS: In the beginning, I just wanted to show people what I had seen during my travels, what I had lived through. In the beginning, therefore, the camera was just a way of documenting my voyages and my experiences. Then, I understood that cinema had a specific language and I wanted to understand and master that language because it could give my work the perspective of a tale, a story, and thus a different immediacy than that offered by television and other forms of mass consumption; because these forms of mass consumption reduce the problem of migration to a problem of mass; the worst thing for people who have experienced migration is to see their own individuality crushed by a "mass" identity. On the contrary, cinema needs individuals in order to tell a story: I cannot tell a story or describe a social problem from a person's perspective without the person, their name, their ideas, their aspirations, and their 
fears. Cinema needs the individual, and migrants need cinema to re-emerge as individuals, in order to rediscover their dignity as Human Beings.

CDG: You say that cinema needs individuals as bearers of a singularity in order to tell a story. Can we explore that idea further and talk about how you make films using awareness of what is implied in the act of migrating - which are also a way of recognizing migrant men and women - in order to present that awareness and thus allow us to (re-)act? Films where awareness, when expressed with emotion, can become an opportunity for commitment for the spectator?

AS: My objective is to change the perspective of things, to change and then "contaminate" that perspective, I have always talked about what it means to live with the consequences of political choices - choices relating to the definition of a social problem - by showing the lives of people who are the real victims of those choices. This is obvious in films such as Come un uomo sulla terra (2008), Mare Chiuso (2012), and Il sangue verde (2010): individuals who suffer the consequences of political choices that were made in response to a definition of a social problem that has nothing in common with their own life or their point of view; choices that are closer to the attitude of Europeans, Italians and their politicians. Let me explain: for example, if I - as an Italian - say and think that I am afraid of immigrants, that I do not know what to do, and if Italian politicians start defining migration and migrants in terms of "barriers", "problem of disembarkation", or of questions such as "how many are arriving?", "where do we put them? There is not enough room even for Italians!" We can easily see how, with these sorts of parameters, the debate will soon focus on: "how can we stop them?", "how can we deport them?", "how can we reduce the numbers?" Choices based on this discourse will completely change the lives of people who are imprisoned, chased, killed, deported. Telling the story from their perspective does not mean that I am involved in a humanitarian mission, but that I am trying to confront two points of view that, in other circumstances, would not be placed side by side. Cinema can do this, because it needs empathy and identification with the story in order to function properly. In other words, the public must identify with the characters, their aspirations, their hopes and fears, so that they can laugh and cry with them. Think of the many films we have seen, where we know the story by heart and we know that it will end badly, yet each time we watch them, we always hope that they will end differently. This is how the magic works: not because the films end badly, but because we always hope that they will end well. Cinema can work the same magic for migration.

Box 1: The Documentary Film-Maker, the Interviewee and the Witness: about Mare Chiuso

In 2009 , about 1,000 exiled Africans sought to reach Italy by sea before being intercepted and returned to Libya. This moment of history, and more precisely 6 May 2009, was the theme for Mare Chiuso, a documentary film based on previously unpublished investigations. It looks into the obstacles faced by exiled people during their journey. Interviews with these migrants provided detailed information on their journeys while conferring on them an inherent value. In addition, this study was enriched by videos produced by the migrants themselves using mobile telephones to talk about their impressions, their deceptions and, more generally, their emotions in situ after an Italian navy boat took them aboard prior to sending them back to Libya. During this process, the transformation of these amateur videos into a documentary film, in which the exiled person acts as a 
witness of their own story, reverses the asymmetric relationship between interviewer and interviewee and provides a more general perspective; it is less aesthetic, more ethnical and more political. ${ }^{11}$ By displaying places - a closed sea and unexpected scenes of migration from a different angle and by setting aside the filter of political and media reports, these stories become symbolic of a representation and a preservation of self (Baker and Blaagaard, 2006).

CDG: Contributing to the emergence of a better world can be achieved through contact with Otherness, through encounters with unfamiliar people. For example, Rancière wrote that cinema is how "these presences accumulate and settle within ourselves to the extent that their reality fades and changes" (2011: 12). How do your films work with these presences, these migrants whose portrait you expose, and how do they take into account the fundamental otherness of living in community? Can we define your work as operating in a space of verisimilitude, while telling a "counter-history" of migration without reference to dominant communication media?

AS: Yes, there is a side to my work that is obviously linked to available information and I do not deny it, even if I am not a journalist. I often work with journalists, they have a great capacity for investigation, research and access to information. I also read the newspapers a lot. In fact, before making my films, I spend a lot of time gathering information and studying. It's important for my films that they fulfil the role of informer, that they are used in Italy and in other countries to inform people. But this cannot be their only role or I would be betraying the cinema's ability to create empathy. If I only inform people, I am stifling my films, because I force their storyline to ignore the protagonists, it merely links them to the research objective and that - for me, as a film-maker - is very serious. This is why, after a while, I made Io sono $\mathrm{Li}$ (2011) and Il sangue verde (2010) which were not supposed merely to provide information, but which aspired to being metaphors for the transfer of information. Some of my films have been used for opening up the debate and discussions on current and specific themes, even for very local and targeted groups. But they are not really a vehicle for information.

CDG: Your documentary films witnessed the meeting of improbable worlds, worlds that were not destined to cross paths and were now becoming connected; this "connectability" operates at various levels of action, from solidarity to denial and violence. You have stressed the importance of metaphor and poetry for putting these (non-)relationships into perspective. Fables and fairy stories are never very far from the narrative constituted in this way. How does cinema make possible or permit what other media do not permit?

AS: For me, cinema is an excellent means for pursuing narrative and physical, truly physical, corporal objectives, as a way of generating not only a collective discussion, but also a private emotion. Theatre is more a forum for private emotions but rarely inspires a public debate, whereas television and Internet create a virtual discussion, a public discussion drawing on a physical "non-co-presence"; cinema, however, requires the participant to be physically present. Thanks to this physical presence, cinema brings together private emotion and public discussion. Therefore, films need to be shown in cinemas, in several different cinemas, but also in universities, cultural associations, libraries, outdoors, and in the street. Films are made for large screens and collective audiences; people have to come together in the same room at the end of the 
film. I make films for them, for those rooms, those places; later, they can be broadcast on television, seen at home, on DVD, etc. but they will no longer have the same impact. Let me give you an example: I made a film last year called Come il peso dell'acqua (2014). This was a film that combined theatre and documentary and I made it for television. It was first shown on the Rai 3 television channel..$^{12}$ At the time, I realized that I had made a mistake because in fact, I had not made a film for television and so television viewers did not really understand, they were not very happy. For my part, I was not satisfied and the film was not a great success. Some 700,000 or 800,000 people watched it, not a high rating for a prime time slot ${ }^{13}$ on Rai 3 which normally has an audience of 3 to 4 million. This was because I had once again made a film for cinema screens, and not for television. I asked the television company for permission to show the film in cinemas, so that it could be screened in schools and universities. At first, the television company did not want to grant me permission, as they owned the rights, but once they understood that the film could be more effective, we set up 200 to 300 screenings throughout Italy and it is still being screened in several places. People who saw the film in a cinema were active citizens in the place where they saw the film. Thus, we see the social outcome that cinema can produce. Cinema cannot change today's world. In the world of media, in the globalized world, cinema does not have the power to change the vast flows of the masses, the flows that politicians need, with which they develop their consensus, the flows that are consumed in the media with unprecedented rapidity. On the other hand, films can say to someone or to a group of people that we do not have to stay inactive and that something must be done. They will later become an active minority and participate in actions for change. Over the years, my films, well, not just mine of course, have helped many Italians - and others - to create welcoming and solidarity projects that counter the closed barriers and conflicts put in place by macropolicies. This leads to a welcoming environment in various locations in Italy and to a different approach to the history of immigration. I know dozens and dozens of migrants, refugees whose lives have been truly enhanced by meeting local people, whether Italian or second generation migrants, who have set up places offering a welcome, a dialogue and a chat, places that have changed the lives of migrants. Some of these people have decided to act, to become involved after seeing my films and those of others.

CDG: To sum up then, can we say that people who see your films and documentaries are in fact invited to demonstrate their "participative observation"? I mean, participation without physical interaction and, on the emotional level, it is possible to develop connivance with the characters on the screen. How does connivance bring people to think differently about distances that drive people away and proximities that bring people together?

AS: Yes, I believe that one of the great errors of humanitarian rhetoric is that it keeps its distance, as can be seen in the organization of symbolic actions of solidarity for "poor migrants who suffer, or come from Countries Without Hope, who flee and must be helped". Yet this type of communication produces distance and allows people to have a clear conscience. Participating in candlelight parades for the "poor migrants who have died" is just a great democratic hypocrisy. To avoid becoming democratic hypocrites and rather to become actively democratic persons, we should always ask ourselves "what is our responsibility?" or "where do we assume these responsibilities?" To answer these questions, we must first ask ourselves which political choices have led to such outcomes and discover for what reason such political choices were made 
possible. Politicians are not horrible beasts who live in another world, they take measures that will benefit their careers, that is to say, succeed in creating a consensus. They should only act for the public good, but too often they just want to further their career. Everyone knows this, there's no point in tiptoeing around it. So when politicians' actions work towards creating a consensus, we have to ask ourselves "why do they create a consensus?", "what are the public circumstances that allow a politician to think that they are certain of creating this consensus?"

This is one of the responsibilities of a civil society that is accountable for such acts and policies. When there are negative consequences, where people die who should not die, it is important that we ask ourselves about our own responsibilities. In addition, there is a "foreign body" that relieves us of our responsibilities: human traffickers. The "campaign against human trafficking" has been around for a long time, but it serves only to relieve us of our responsibilities. All the migrants I know, if they could take a ferry or a boat, they would never climb into a trafficker's boat. Every single one of them. So the question is: "why don't they take the ferry... since the ferry from Tunis to Palermo takes only four hours". I can take that ferry, but they cannot. "Why can I take a plane from Syria or Istanbul for fifty euros? Why can I, and not them?", "Why do they all want to come here?" These questions are never asked. The questions that are asked focus on: "What can we do to stop the traffickers? How can we control the flow and quantity of migrants? What should we do to manage all the migrants?" If we were asking these questions, the answer would be: "Fight the traffickers, put an end to these voyages, etc., etc." I believe that this responsibility exists at several levels, even in our daily lives, whenever we take a position on a subject that could become a "political responsibility".

Cinema needs us to watch responsibly, to create an emotive response, but cinema goes further than that. It accompanies and criticizes the film's storyline, demanding that we do not just watch and react emotionally. If something does not work properly, we should say to ourselves “no, I don't believe this, I don't believe this scene". Sometimes, when we watch a film and we say "I didn't believe that scene", that means we are responsible for our attitude and that we are ready to criticize this situation, and we can then talk about it with others. This collective responsibility demanded by a film from each spectator is similar to the collective responsibility that the civil society should be developing.

CDG: How does this collective responsibility, as expressed through fiction, function? How do you mobilize the specific forms of expression that cinema offers? For example, using editing techniques that place the present against the background of history, as a way to open up to other worlds and to expand the range of opportunities?

AS: What I do in my films is, I always leave space in which people who are ready to hear can formulate their reaction. I mean, there are moments in my films where, through my technical and aesthetic choices, I can create a space for the spectators and ask them to use that space to reflect on what is happening and to collaborate with the narrative by adding value, making sense of what has just happened. It is difficult, I feel it and test it, I don't know, it is difficult to put it into words. There are moments in my films where the plot stops and I say to the spectator: "Now, put in whatever you like from your life, your thoughts based on what you have just seen". Let's take an example from Io sono $L i$, the scenes where the girl, Ian's friend, is doing Tai Chi. ${ }^{14}$ These are scenes where I do not decide on their semantic value, but I create a space in which the spectators can 
introduce their own semantic values in the hope that they can collaborate and become co-responsible for what is being said. Similarly, there are moments in my documentaries where the protagonists do not talk, but just look, sometimes into the camera, they look straight into the camera as if they are looking at the spectator and saying: "What do you think now? What were you doing while I was telling you that?" That's an example.

26 I believe that it is very important not to make the objective explicit, not to tell the spectators that they are responsible, that they should participate. If I said: "You must think!" that would be explicit and without a doubt, I would create a conflict by this "You must think!" wouldn't I? I would create opposition and a refusal of my invitation which becomes vertical. On the contrary, I want to create a horizontal space where spectators can interact in their own way through an implicit request to participate.

CDG: This horizontal space in which spectators can relate to the characters and develop an empathic relationship is created by the production of images that "allow [spectators] to see", allow them to live through and share the experience. In your films and documentaries, I was conscious of the way you handle paternal and maternal figures and of the images that move us and highlight the role of parents in migration, including in situations of separation and distance. These images, these constellations where the past meets the present to quote Benjamin (2000), shift the viewpoint and restore the fundamentally human dimension, and indeed the family dimension of migration.

AS: Yes, I believe that this is part of an unconscious heritage from Italian cinema, all meaningful Italian films focus on fathers, mothers and children, family. This is a cognitive tool, a daily experience that plays an important role in our culture, in Italian anthropology. In fact, when I want to make a film that touches the sensitivity of many people, using the mother-child relationship works in Italy: so it is a good tool for me when I want to open up the emotional impact.

Then, if we take this idea one step further, we can say that it is not just about the mother-child relationship, it is also about a relationship between me and another, a universal relationship in which rapports with the Other play a part. In any event, perhaps yes, showing the relationship between a mother separated from her son who are thus unable to see each other makes it possible for Italians to understand that this is a problem. This point of departure allows us to move towards a more complex relational dynamic that is no longer the specific case of this family, but constitutes an exchange between this small family community and a more complex community that we must begin to understand. In Italy, Io sono Li has been seen by many people and a large proportion of them were women around the age of fifty, according to demographic statistics. Many fifty-year-old women have seen the film and many of them, in the letters I have received, write about their emotion when the son arrives at his mother's house: that means we have changed the point of view. It is no longer a question of "the Chinese who buy our bars", but of a mother who waits for her son and, while she waits, she works in a restaurant; it is a different approach, a change of standpoint generated by this mechanism.

CDG: In your last film, the images that crystallize the relationship with identity and otherness are anchored in a landscape and an imagery of limitations, the steppe, and also frontiers: places where people stop, but never stop going. 
AS: Yes, that's right. My latest film is called I sogni dell'anno salato (2015). It takes place in Kazakhstan, where the relationship between economic development and humanity is experienced through the story of "other" people, the Kazakhs, and people closer to me, my mother and father. The relationship described in this film is very strong and, for the first time, we even hear my voice because I show images from the 1950s and 1960s; in my opinion, it was only right that I should be present. Nevertheless, it is not a film that talks about me and my family; on the contrary, it is a film in which each person can place a part of their own family, their own story and which talks about the global economy.

Box 2: Cinematographic Treatment of Migration in Italy: A Few Landmarks

Although Italy has now become one of the new countries of immigration and has generated a growing interest in the cinema, many Italian film-makers initially focused on Italian emigration to other countries; America, France, Belgium, Germany, which were the main destination countries for this mainly economic migration. Among the most significant are Il cammino della speranza (Pietro Germi, 1950), Pane e cioccolata (Franco Brusati, 1973), Sacco e Vanzetti (Guiliano Montaldo, 1971), The Godfather (Francis Ford Coppola, 1972), The Golden Door (Nuovomondo) (Emanuele Crialese, 2007). These films concentrate on clandestine and emigrant characters and stress the difficulties they face during their migration and after their arrival in countries of destination (here France, Switzerland, and America). During the 1960 s when Italy was seen as a country of immigration, ${ }^{15}$ films on this theme were booming. As Italian cinema cannot count on second-generation immigrants - as seen in France's beur cinema - who would construct their own vision of the immigration question, it offers a specific cinematographic treatment of the "foreigner". Among the film-makers who have marked this new direction in Italian cinema are Vittorio Moroni with a film about a young Muslim labourer born in Bangladesh and living in Rome (Le ferie di Licu, 2006), Giorgio Diritti who portrays the foreigner as an indicator of cultural differences (Il vento fa il suo giro, 2005), and Carmine Amoroso who talks about the disillusions of youth through the story of a young economic migrant in Italy (Cover Boy: l'ultima rivoluzione, 2008).

\section{BIBLIOGRAPHY}

Agier Michel (2002) Aux bords du monde, les réfugiés, Paris, Flammarion, 186 p.

Baker Mona and Blaagaard Bolette B. (2006) Citizen Media and Public Spaces. Diverse expressions of Citizenship and Dissent, London, Routledge, $262 \mathrm{p}$.

Barrère Anne et Martuccelli Danilo (2009) Le roman comme laboratoire. De la connaissance littéraire à l'imagination sociologique, Lille, Presses universitaires du septentrion, $336 \mathrm{p}$.

Barthes Roland (1975) En sortant du cinéma, Communications, 23 (1), pp. 104-107. 
Becker Howard (2010) Comment parler de la société ? Artistes, écrivains, chercheurs et représentations sociales, Paris, Éditions La Découverte, 308 p.

Benjamin Walter (2000 [1940]) Sur le concept d'histoire, in Euvres III, Paris, Folio, pp. 427-443.

Berthomière William et Hily Marie-Antoinette (2006) Décrire les migrations internationales. Les expériences de la co-présence, Revue Européenne des Migrations Internationales, 22 (2), pp. 67-82.

Bessy Marianne et Salmon Carole (Éds.) (2016) Racines et déracinements au grand écran. Trajectoires migratoires dans le cinéma français du XXIe siècle, Leiden, Boston, Brill, $222 \mathrm{p}$.

Chalvon-Demersay Sabine (1996) Une société élective. Scénarios pour un monde de relations choisies, Terrain, 27, pp. 81-100.

Darnis Jean-Pierre (2010) L'immigration, enjeu de politique intérieure et de politique étrangère pour l'Italie contemporaine, Italie. Revue d'Études Italiennes, 14, pp. 203-215.

Del Biaggio Cristina (2014) Vaincre une mer déserte et fermée, VisionsCarto.net, [en ligne]. URL : http://archive-ouverte.unige.ch/unige:48368

Ethis Emmanuel (2005) Sociologie du cinéma et de ses publics, Paris, Armand Colin, 127 p.

Eugène Pierre (2015) Mobilis in Mobili. L'émotion de l'histoire chez Serge Daney, Critique, 814 (3), pp. 178-190.

Ferro Marc (2008) Cinéma et immigration postcoloniale, in Nancy L. Green et Marie Poinsot Éds., Histoire de l'immigration et question coloniale en France, Paris, La Documentation française, $280 \mathrm{p}$.

Gastaut Yvan (2001) Cinéma de l'exclusion, cinéma de l'intégration. Les représentations de l'immigré dans les films français (1970-1990), Hommes \& migrations, 1231, pp. 54-66.

Ma Mung Emmanuel (2000) La diaspora chinoise, géographie d'une migration, Paris, Éditions Ophrys, $175 \mathrm{p}$.

Rancière Jacques (2011) Les écarts du cinéma, Paris, La Fabrique, 158 p.

Simon Gildas (2008) La planète migratoire dans la mondialisation, Paris, Armand Colin, 255 p.

Weber Max (2004 [1905]) L'Éthique protestante et l'esprit du capitalisme, Paris, Gallimard, 602 p.

\section{APPENDIXES}

\section{Andrea Segre Filmography}

1998: Lo sterminio dei popoli zingari, documentary.

1999: Berlino 1989-1999 - Il muro nella testa, documentary.

2001: Ka drita?, documentary.

2001: A metà - storie tra Italia e Albania, documentary.

2001: Dalle tre alle tre - Il Nord-Est e il Mare, documentary.

2003: Marghera Canale Nord, documentary.

2004: Dio era un musicista, feature film.

2005: $1 \mathrm{~kg}$ di internet, documentary.

2006: Kerchaou, documentary. 
2006: PIP49, documentary.

2007: La Mal'ombra, documentary.

2008: Come un uomo sulla terra, documentary.

2009: Magari le cose cambiano, documentary.

2010: Il sangue verde, documentary.

2011: Io sono Li [La Petite Venise], feature film.

2012: Mare chiuso, documentary co-directed with Stefano Liberti.

2013: La prima neve, feature film.

2013: Indebito, film written with Vinicio Capossella.

2014: Come il peso dell'acqua.

2015: I sogni dell'anno salato, documentary.

\section{NOTES}

1. This text is a translation of the article published in REMI vol. $32 \mathrm{n}^{\circ} 3 \& 4$ (2016). It was translated by Caroline Mackenzie and financed by a grant from LAMES (UMR 7305).

2. Cf. the debate following the release of Indigènes (2006) a film by Rachid Bouchareb. This led to a reassessment of the role played by France's colonial soldiers in the liberation of France in 1945 and a decision by the then French President Jacques Chirac to realign pensions for foreign veterans with those of French veterans.

3. "I am not a member of any film school and, for a long time, I hesitated about becoming a filmmaker rather than a university researcher... My two professional careers are linked by a profound desire to recount the life and story of migrants. So I began to travel in opposite directions, from East to West Europe, from the Balkans to Africa", Extract from Univers ciné (2012) Andrea Segre: "With films, I can show reality and dream at the same time", 15 June 2012 [online]. URL: http://www.universcine.com/articles/andrea-segre-avec-le-cinema-je-peux-montrer-larealite-et-rever-aussi

4. This narration is based notably on portraits, the significance of places, ambiances and landscapes which situate people in a given space and time. These narrative techniques emerge as "passages" between different forms of perception in society (Barrère and Martuccelli, 2009).

5. In order to appreciate Andrea Serge's contribution to Italian film production, a box on "The cinematographic treatment of migration in Italy: some key elements" appears as an appendix to this interview. In addition, with regard to interpretation of immigration dramas through cinema, cf. Le Gouez Brigitte (2015) Un réalisateur enquête : Andrea Segre entre éthique, esthétique et politique, presentation at the conference on Le cinéma italien d'aujourd'hui entre film politique et film engagé, Caen 15-16 October 2015.

6. A box on "The documentary film-maker, the interviewee and the witness: about Mare Chiuso", in the middle of this interview, reviews the specific contribution of documentary films in creating new forms of surveys.

7. Favier Olivier (2014) La prima neve : le réel au croisement des cultures. Entretien avec Andrea Segre, [online]. URL: http://dormirajamais.org/segre/

8. Non-governmental organizations.

9. For information, in terms of the arrival of migrants, Italy $(307,500)$ was ranked fourth in Europe in 2013, after Germany $(692,700)$, the United Kingdom $(526,000)$, and France $(332,600)$. 
Source: Eurostat. Statistiques sur la migration et la population migrante, [online]. URL: http:// ec.europa.eu/eurostat/statistics-explained/index.php/

Migration_and_migrant_population_statistics/fr\#Informa

10. Friends and colleagues with whom Andrea Segre has created a collective of "social film" directors. Cf. site of ZaLab Association for the production, distribution and promotion of social documentaries and cultural projects: http://www.zalab.org/

11. In 2012, the European Court of Human Rights condemned Italy for non-respect for the right of exiles to obtain refuge when they know their life is in danger (Del Biaggio, 2014).

12. National television channel in Italy.

13. I.e. at $9 \mathrm{pm}$.

14. On the presence of Chinese people in Italy and more widely in Europe, cf. Ma Mung, 2000.

15. We should mention that, since the early 1970 s, Italy has progressively become a country of immigration starting with a statistically small presence of foreigners. It was not until the 1990s, when the volume of migratory flows increased substantially, that Italy began to see itself as a country of immigration (Darnis, 2010). Today, the migratory situation in Italy covers a range of concurrent movements of population: immigration, emigration and internal mobility. Cf. REMI, issue coordinated by P. Corti and A. Miranda on Italy at the crossroads of migratory movements (to be published).

\section{ABSTRACTS}

For several decades, migratory issues have become an important subject for contemporary societies whose cinema has played a major role. As a source and research tool, the cinema helps us understand the history of migration and underlines the way in which society deals with alterity through the mobilisation of the foreigner. The interview with Andrea Segre, famous director and scriptwriter of internationally acclaimed documentaries and films, highlights the capacity of the cinema to open up news worlds - and not only to reflect existing ones. In these worlds, differences between people not so much an obstacle but the foundation of our common humanity.

Depuis quelques décennies, les questions migratoires sont devenues un sujet majeur des sociétés contemporaines dont le cinéma se fait le relais. Considéré comme source et outil d'analyse, celuici contribue à la connaissance de l'histoire des migrations et souligne la façon dont une société construit son rapport à l'altérité en mobilisant la figure de l'étranger. L'entretien mené auprès d'Andrea Segre, réalisateur et scénariste italien de documentaires et de films internationalement reconnus et primés, met en lumière la capacité du cinéma à ouvrir des mondes possibles - et non seulement à refléter ceux existants -, des mondes où les différences sont moins un obstacle à la commune humanité qu'un de ses fondements.

Desde hace algunas décadas, las cuestiones migratorias se han convertido en un tema mayor de las sociedades contemporáneas de las que el cine se hace eco. Considerado como fuente y herramienta de análisis, el cine contribuye al conocimiento de la historia de las migraciones y remarca la manera en la que una sociedad construye su relación con la alteridad a través de la figura del extranjero. La entrevista con Andrea Segre, director y guionista italiano de documentales y películas reconocidos y premiados a nivel internacional, pone de relieve la 
capacidad del cine para abrir nuevos mundos posibles - y no solo para reflejar los ya existentes -, mundos donde las diferencias no son tanto un obstáculo para la humanidad común, sino uno de sus fundamentos.

INDEX

Palabras claves: cine, Andrea Segre, historia de las migraciones, extranjero, relación de alteridad, sociedades contemporáneas

Keywords: cinema, Andrea Segre, history of migration, foreigner, deals with alterity, contemporary societies

Mots-clés: cinéma, Andrea Segre, histoire des migrations, étranger, rapport d'altérité, sociétés contemporaines

\section{AUTHOR}

\section{CONSTANCE DE GOURCY}

Sociologist, Lecturer, LAMES, Aix-Marseille University/CNRS, 3-29 avenue Robert Schuman, 13628 Aix-en-Provence; constance.degourcy@univ-amu.fr 